\title{
The Effect of COVID-19 Vaccinations in 47 European Countries
}

\author{
Umberto Cornelli and Giovanni Belcaro
}

\section{ABSTRACT}

Background: in the 47 European countries the vaccination against COVID19 started between December 2020 and January 2021. However, the first wave (W1) was controlled without any vaccine administration

Objective: to analyze the effect of vaccines on COVID-19 deaths rates, comparing the $\mathrm{W} 1$ with last wave (W2)

Methods: deaths rates from March 2, 2020, up to May 10, 2021, were recorded from WHO dashboard

The same was for the vaccine doses administered up to the May 9-11, 2021.

The trends of the deaths during W1 were followed for 5 weeks after the peak (6 values), while for the W2 the last 6 weeks from April 5 to May 10, 2021 were considered.

Results: the vaccination coverage was between $<2 \times 10^{3}$ inhabitants (Armenia) and $831 \times 10^{3}$ (UK) and the average was $395 \times 10^{3}$ inhabitants. Although some differences among countries in the coverage, it seems that vaccination is significantly accelerating the deaths decay which was correlated with the doses administered.

Conclusions: in Europe the decay of deaths due to Covid-19 during the 2020 (W1) was achieved without any vaccination program. However, the vaccine is significantly decreasing the deaths rate proportionally to the amount of doses administered.

Keywords: COVID-19; Vaccines; European Countries.
Submitted : May 23, 2021

Published : June 30, 2021

ISSN: 2593-8339

DOI: $10.24018 /$ ejmed.2021.3.3.889

Umberto Cornelli *

Loyola University Medical School Chicago, IL, USA.

(e-mail: ucornelli@gmail.com)

Giovanni Belcaro

Darwin Lab \& Irvine 3 Labs and the OOLEX C-Virus project, Spoltore (PE), Italy.

(e-mail: cardres ${ }^{@}$ abol.it)

*Corresponding Author

\section{INTRODUCTION}

The COVID-19 at May 102021 was causing 3,364,664 deaths in the World, and only in Europe they were $1,121,670$ (about $33 \%$ ) with at rate death/inhabitants which corresponds to the highest rate compared to the rest of the World [1].

In Europe the vaccination program started immediately after the approval of the different Governments, and between December 2021 up to May 10 about 270 million of doses were administered covering as average $395 \times 10^{3}$ inhabitants. Since most the available vaccines (see Table I) have to be administered twice, the real coverage is less than $200 \times 10^{3}$.

During the first wave (W1) of COVID-19, no vaccine was available and in Europe the deaths rate was diminishing from $4.2 \times 10^{5}$ down to 0.2 in July 2020. In USA, Brazil, India, and Russia in July the deaths rate was about 20 times higher and kept the virus alive with the consequences that Europe was aggressed again reaching deaths $>5 \times 10^{5}$ inhabitants.
It is evident that immediately after the vaccination start, an increase of death was taking place, which can be consistent with the 3-4 weeks needed to generate a sufficient amount of antibodies [2], [3].

However, after a first decay of about $50 \%$ of deaths during January and February 2021 the rate increased again in all the month of March, and in April only a constant decay was taking place (Fig. 1).

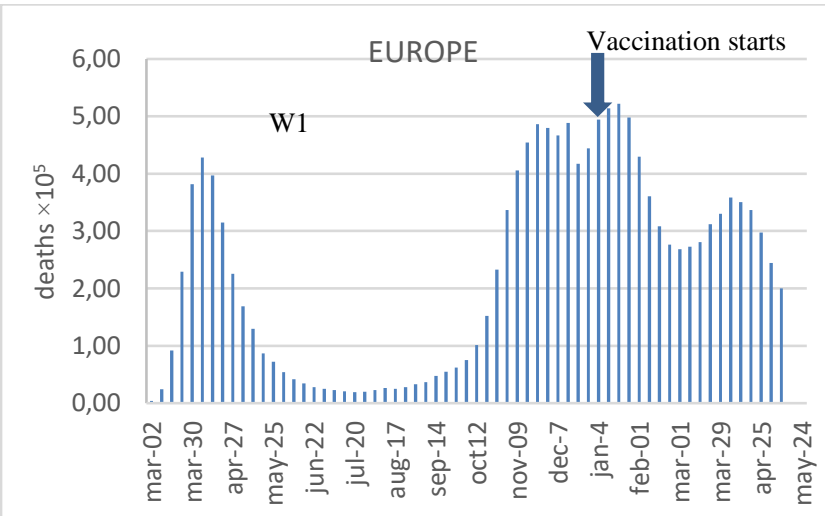

Fig. 1. Deaths $\times 10^{5}$ in Europe from March 2, 2021, up to May 10, 2021 . 
The question arising is whether the decay was due to the vaccinations or belongs to a sort of "natural" decay of the viral aggression, as it was happening during W1 when the only available tools were the lockdown, the mask wearing, the hands disinfection and the distance among people.

In other terms, what is the real advantage of vaccines in terms of life saving, which is a crucial question due to the direct and logistics cost of vaccination that will reach several billion of Euro.

It is known that on May 22 almost all countries outside Europe (136 countries) were not providing vaccinations which is now reaching the rate of 27 million of doses/day [4].

The object of the present study was to compare the decay of deaths during W1 with the decay of deaths following the vaccinations in the 47 European countries.

\section{METHODS}

Forty-seven European Countries were considered (see Table I).

These are more than those part of the European Union (EU) and all belong to the European Council.

The deaths and vaccine doses were retrieved from the WHO dashboard updated to May 10 (for vaccinations in some country up to May 12). The weekly data of deaths were considered.

Two set of data were compared: for W1 (2020), the week of the peak ad the 5 weeks immediately after the peak were considered; for the last wave (W2) the 6 weeks from April 5 to May 10, 2021, were considered.

W1 has a different length in each country, but approximately it is lasting from March to July-August 2021, while W2 started approximately a July-August 2020 and its values were considered up to May 10, 2021.

\section{A. Statistical Analysis}

The deaths decay was calculated using the "b" value of the regression curves. The weekly values of the 6 weeks after the peak of the phase W1 and the 6 terminal weeks after the vaccinations were compared. The differences of the b values for each country were calculated according to the Profiler Analysis and the Mann Whitney U test was used to compare the two sets of $b$. The correlations among variables were calculated using the Spearman's $\rho$. The SAS university edition was used for all the calculations.

\section{RESUlTS}

The deaths $\times 10^{5}$ inhabitants during $\mathrm{W} 1$ and $\mathrm{W} 2$ are reported in Table I.

According to the arbitrary periods used to define W1, the deaths in Europe were 189,072 while during the W2 up to May 10 the deaths were 788,125 (4.2 times higher).

In all the countries W2 deaths were higher, from 1.1 times (San Marino) up to 476.2 times (Montenegro).

The vaccine under use is reported in Table II.

No data are available on the quantity of the single vaccine administered in all the 176 countries.

The precise amount used in each county for the moment is not known and, a part of UK, all the other countries were using more than one vaccine. The Johnson\&Johnson vaccine is the only to be administered once, while all the other need two administrations. However, this last vaccine was approved by Europe only in the month of April and few doses were used compared to all the other.

The vaccination coverage is reported in Table III.

TABLE I: DEATHS $\times 105$ INHABITANTS IN THE 47 EUROPEAN COUNTRIES AND THE DEATH RATIO BETWEEN THE TWO WAVES W1 AND W2

\begin{tabular}{|c|c|c|c|c|c|c|c|}
\hline Country & $\begin{array}{c}\text { Deaths } \\
\mathrm{W} 1 \times 10^{5}\end{array}$ & $\begin{array}{c}\text { Deaths } \\
\mathrm{W} 2 \times 10^{5}\end{array}$ & $\begin{array}{c}\text { Ratio } \\
\text { W2/W1 }\end{array}$ & Country & $\begin{array}{c}\text { Deaths } \\
\mathrm{W} 1 \times 10^{5}\end{array}$ & Deaths W2× $10^{5}$ & $\begin{array}{c}\text { Ratio } \\
\text { W2/W1 }\end{array}$ \\
\hline Albania & 0.98 & 78.02 & 80.0 & Liechtenstein & 2.70 & 143.24 & 53.0 \\
\hline Andorra & 63.75 & 95.00 & 1.5 & Lithuania & 2.68 & 137.00 & 51.0 \\
\hline Armenia $^{\text {a }}$ & 30.98 & 113.80 & 3.7 & Luxembourg & 20.00 & 126.55 & 6.3 \\
\hline Austria $^{a}$ & 8.62 & 111.31 & 12.9 & Malta & 2.12 & 96.94 & 45.8 \\
\hline Azerbaijan ${ }^{a}$ & 65.17 & 42.55 & 6.9 & Moldova & 37.29 & 173.65 & 4.7 \\
\hline Belgium $^{\mathrm{a}}$ & 86.92 & 132.00 & 1.5 & Monaco & 2.56 & 79.49 & 31.0 \\
\hline Bosnia & 4.22 & 230.58 & 54.6 & Montenegro & 0.08 & 40.32 & 476.2 \\
\hline Bulgaria & 2.00 & 244.43 & 122.2 & Netherlands a & 36.48 & 76.28 & 1.8 \\
\hline Croatia & 2.52 & 178.59 & 71.0 & North Macedonia & 4.72 & 245.73 & 52.0 \\
\hline Czechia & 3.10 & 278.44 & 89.8 & Norway $^{a}$ & 4.94 & 10.05 & 2.0 \\
\hline Cyprus & 1.56 & 27.42 & 17.6 & Poland & 4.28 & 180.20 & 42.1 \\
\hline Denmark $^{a}$ & 11.02 & 33.23 & 3.0 & Portugal & 17.02 & 148.41 & 8.7 \\
\hline Estonia $^{a}$ & 4.79 & 88.07 & 18.4 & Romania & 6.61 & 141.21 & 21.4 \\
\hline Finland $^{\mathrm{a}}$ & 5.99 & 10.95 & 1.8 & San Marino & 127.27 & 145.45 & 1.1 \\
\hline France $^{a}$ & 47.06 & 119.99 & 2.6 & Serbia & 3.25 & 91.23 & 28.1 \\
\hline Georgia & 0.40 & 110.07 & 295.1 & Slovakia & 0.52 & 231.14 & 447.5 \\
\hline Germany ${ }^{a}$ & 11.24 & 95.53 & 8.5 & Slovenia & 5.48 & 207.51 & 37.9 \\
\hline Greece & 1.79 & 103.20 & 57.6 & Spain $^{a}$ & 64.26 & 84.58 & 1.3 \\
\hline Hungary & 6.03 & 289.35 & 48.0 & Sweden ${ }^{a}$ & 59.47 & 77.66 & 1.3 \\
\hline Iceland & 2.87 & 5.46 & 1.9 & Switzerland ${ }^{\text {a }}$ & 20.88 & 95.01 & 4.6 \\
\hline Ireland ${ }^{a}$ & 38.24 & 69.37 & 1.8 & Turkey $^{\mathrm{a}}$ & 7.07 & 48.06 & 6.8 \\
\hline Italy $^{\text {a }}$ & 57.79 & 146.27 & 2.5 & Ukraine & 1.86 & 122.00 & 60.2 \\
\hline Kosovo & 1.15 & 120.49 & 104.4 & United Kingdom $^{\text {a }}$ & 64.32 & 133.33 & 2.1 \\
\hline Latvia & 1.55 & 111.24 & 71.8 & Europe total deaths & 189072 & 788125 & 4.2 \\
\hline
\end{tabular}

$\mathrm{a}=$ countries with a clear $\mathrm{W} 1 \mathrm{where}$ is possible to identify clearly a peak and a decay. 
TABLE II: VACCINES CURRENTLY AVAILABLE IN THE WORLD

\begin{tabular}{|c|c|c|c|c|}
\hline $\begin{array}{l}\text { Vaccine name } \\
\text { Country }\end{array}$ & Kind of vaccine & Producer & $\begin{array}{c}\text { Efficacy \% } \\
\text { Doses }\end{array}$ & Ref \\
\hline $\begin{array}{c}\text { mRNA-1273 A } \\
\text { USA }\end{array}$ & mRNA & Moderna & $\begin{array}{c}94 \\
2\end{array}$ & 5 \\
\hline $\begin{array}{l}\text { BNT1262b2 A } \\
\text { USA/Germany }\end{array}$ & mRNA & Pfizer-BioNTech & $\begin{array}{c}95 \\
2\end{array}$ & 6 \\
\hline $\begin{array}{l}\text { ChAdOx1 A } \\
\text { USA/Sweden }\end{array}$ & $\begin{array}{l}\text { Non replicating } \\
\text { Viral vector }\end{array}$ & AstraZeneca/Oxford & $\begin{array}{c}67 \\
2\end{array}$ & 7 \\
\hline $\begin{array}{c}\text { Gam-COVID-Vac } \\
\text { Russia }\end{array}$ & $\begin{array}{l}\text { Viral vector } \\
\text { "Sputnik" }\end{array}$ & Gamaleya Res Center & $\begin{array}{c}92 \\
2\end{array}$ & 8 \\
\hline $\begin{array}{l}\text { Sinopharm } \\
\text { China }\end{array}$ & $\begin{array}{c}\text { Inactivated } \\
\text { virus }\end{array}$ & Sinova Biothec & $\begin{array}{c}86 \\
2\end{array}$ & 9 \\
\hline $\begin{array}{l}\text { Coronavac } \\
\text { China }\end{array}$ & $\begin{array}{c}\text { Inactivated } \\
\text { virus }\end{array}$ & Sinovac Biotech & $\begin{array}{c}50-79 \\
2\end{array}$ & 10 \\
\hline $\begin{array}{l}\text { Ad26.COV2.S } \\
\text { USA/Germany }\end{array}$ & $\begin{array}{l}\text { Non replicating } \\
\text { Viral vector }\end{array}$ & Johnson \& Johnson & $\begin{array}{c}66 \\
1\end{array}$ & 11 \\
\hline $\begin{array}{l}\text { Ad5-nCov } \\
\text { China }\end{array}$ & $\begin{array}{c}\text { Non replicating } \\
\text { Viral vector }\end{array}$ & Cansino Biologics & $\begin{array}{c}65.7 \\
1\end{array}$ & 12 \\
\hline $\begin{array}{l}\text { BBV152 } \\
\text { India }\end{array}$ & $\begin{array}{c}\text { Inactivated } \\
\text { virus }\end{array}$ & Barat & $\begin{array}{c}81 \\
2\end{array}$ & 13 \\
\hline $\begin{array}{c}\text { EpiVacCorona } \\
\text { Russia }\end{array}$ & $\begin{array}{l}\text { Subunit } \\
\text { virus }\end{array}$ & Vector Institute & $\begin{array}{c}100 \\
2\end{array}$ & 14 \\
\hline
\end{tabular}

TABLE III: VACCINATION COVERAGE AS DOSES $\times 10^{3}$ INHABITANTS IN THE EUROPEAN COUNTRIES

\begin{tabular}{|c|c|c|c|}
\hline Country & $\begin{array}{l}\text { Doses } \times 10^{3} \\
\text { inhabitants }\end{array}$ & Country & $\begin{array}{l}\text { Doses } \times 10^{3} \\
\text { inhabitants }\end{array}$ \\
\hline Albania & 195 & Liechtenstein & 372 \\
\hline Andorra & 394 & Lithuania & 384 \\
\hline Armenia & 0.2 & Luxembourg & 463 \\
\hline Austria & 433 & Malta & 849 \\
\hline Azerbaijan & 172 & Moldova & 62 \\
\hline Belgium & 424 & Monaco & 665 \\
\hline Bosnia & 28 & Montenegro & 185 \\
\hline Bulgaria & 139 & Netherlands & 397 \\
\hline Croatia & 269 & $\begin{array}{c}\text { North } \\
\text { Macedonia }\end{array}$ & 65 \\
\hline Czechia & 346 & Norway & 370 \\
\hline Cyprus & 292 & Poland & 371 \\
\hline Denmark & 421 & Portugal & 473 \\
\hline Estonia & 403 & Romania & 268 \\
\hline Finland & 400 & San Marino & 1013 \\
\hline France & 402 & Serbia & 540 \\
\hline Georgia & 126 & Slovakia & 343 \\
\hline Germany & 442 & Slovenia & 358 \\
\hline Greece & 338 & Spain & 432 \\
\hline Hungary & 689 & Sweden & 401 \\
\hline Iceland & 421 & Switzerland & 392 \\
\hline Ireland & 408 & Turkey & 312 \\
\hline Italy & 395 & Ukraine & 14 \\
\hline Kosovo & 12 & $\begin{array}{c}\text { United } \\
\text { Kingdom }\end{array}$ & 831 \\
\hline Latvia & 193 & Europe & 395 \\
\hline
\end{tabular}

The vaccination coverage is extremely different among countries, showing a very limited coverage (Armenia, Bosnia, Kosovo, Moldova, Ukraine, and North Macedonia) and relatively high coverage (San Marino, UK, Malta, Monaco, and Hungary). However, most of the countries (34) are in the range between $200-500$ shots $\times 10^{3}$ /inhabitants, and few (6) in the range of 100-200 $\times 10^{3} /$ inhabitants.

The correlation matrix between deaths and vaccination coverage is reported in Table IV.

The correlation between vaccine doses and deaths $\times 10^{5}$ inhabitants become statistically significant two months after the start of the vaccine program. After this period the negative correlation values tends to increase over time and confirm the vaccination efficacy.

In relation to the trends of $\mathrm{W} 1$ and $\mathrm{W} 2$, it was necessary to compare only those countries in which the $\mathrm{W} 1$ was clearly defined. Thirty European Countries were not presenting a trend that could be compared with the W2 because it was not possible to calculate a trend due to the limited number of deaths (see Table I).

TABLE IV: CORRELATION BETWEEN DEATHS AND VACCINE COVERAGE $\left(\times 10^{3}\right.$ INHABITANTS $)$ AT DIFFERENT PERIODS

\begin{tabular}{ccc}
\hline Period & Spearman's $\rho$ & $\mathrm{p}$ \\
\hline January 4 May 10 & -0.0587 & $>0.05$ \\
February 1 May 10 & -0.1903 & $>0.05$ \\
March 1 May 10 & -0.3478 & $<0.05$ \\
March 22 May 10 & -0.4218 & $<0.01$ \\
April 5 May 10 & -0.4515 & $<0.01$ \\
April 25 May 10 & -0.5601 & $<0.005$ \\
\hline
\end{tabular}

An example of this aspect can be represented comparing the deaths rates of Italy (Fig. 2) and Czechia (Fig. 3).

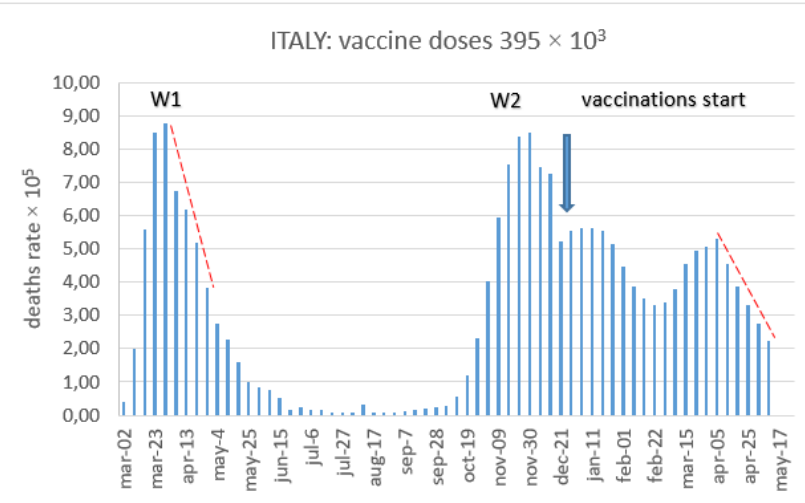

Fig. 2. Deaths rate $\times 10^{5}$ Inhabitants in the period between March 2, 2020 and May 10, 2021. W1= wave 1; W2 = wave 2 .

The red dotted lines represent the decays to be compared.

Two elements are important: a) W1 is well represented with a peak and a decay phase; b) W2 shows 2 phases of decay, the first immediately after the start of vaccinations, and the second initiating on April 5 and continuing up to May 10.

On the light of these findings, two different decay phases of 6 weeks can be analyzed: the first from the peak (March 30, 2020) up to May 4 which is consistent as "no vaccine decay"; the second from the peak of April 5 up to May 10 which is the "vaccine decay".

The same considerations cannot be done in the case of 
Czechia (Fig. 3).

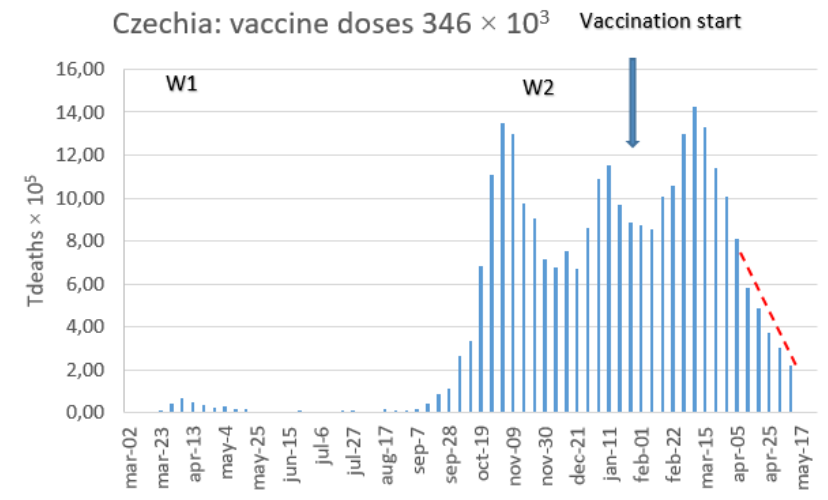

Fig. 3. Death's rate $\times 10^{5}$ Inhabitants in the period between March 2, 2020 and May 10, 2021. W1 = wave 1: W2 =wave 2.

The red dotted lines represent the decay during the last 6 weeks.

In this instance, the W1 was very limited and does not allow to calculate any 6 weeks decay.

This event is happening in 29 out 47 European countries, therefore the decay phases of the 6 weeks before and after vaccination can be compared for 18 countries only.

These countries are reported in Table $\mathrm{V}$ with the relative " $b$ " values representing the angular coefficient of the linear regression.

The average $b$ values after vaccination indicates on the whole the presence of a significant acceleration of the death decay.

However, there are 9 countries (Armenia, Austria, Azerbaijan, Denmark, Estonia, Germany, Italy, Norway, and Turkey) showing that the decay of the two phases is not significantly different, witnessing a limited effect of vaccination (in the period analyzed).

However, among these, Germany, Denmark, Norway, and Turkey have peculiar trends, which can be represented by the data of Germany (Fig. 4 and 5) showing a delay of the decay which was anticipated by an increase.

There are 9 countries where the vaccination significantly accelerates the deaths decay, and these are Belgium,
Finland, France, Ireland, Netherlands, Spain, Sweden and Switzerland.

In case only the last 4 points were considered, the decay phase will have $a b$ value $=-126.58$ indicating a significant acceleration of the decay.

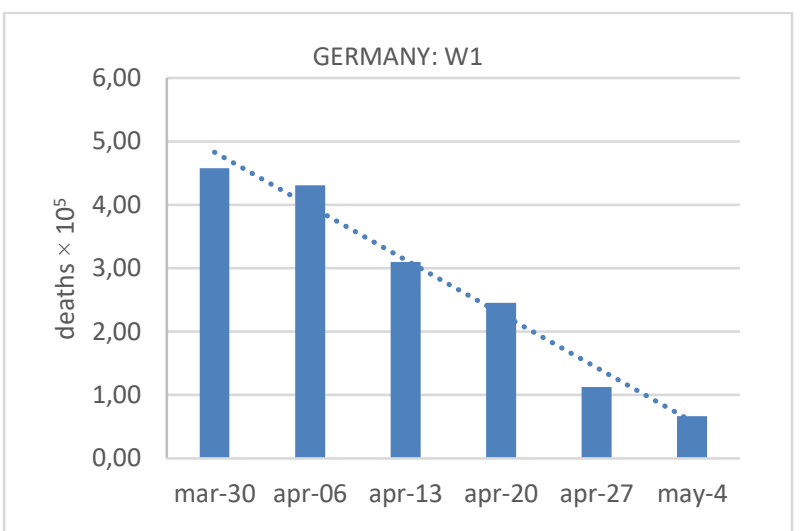

Fig. 4. Trend of the 6 weeks period before the vaccination during W1 in Germany: $b=-21.37$.

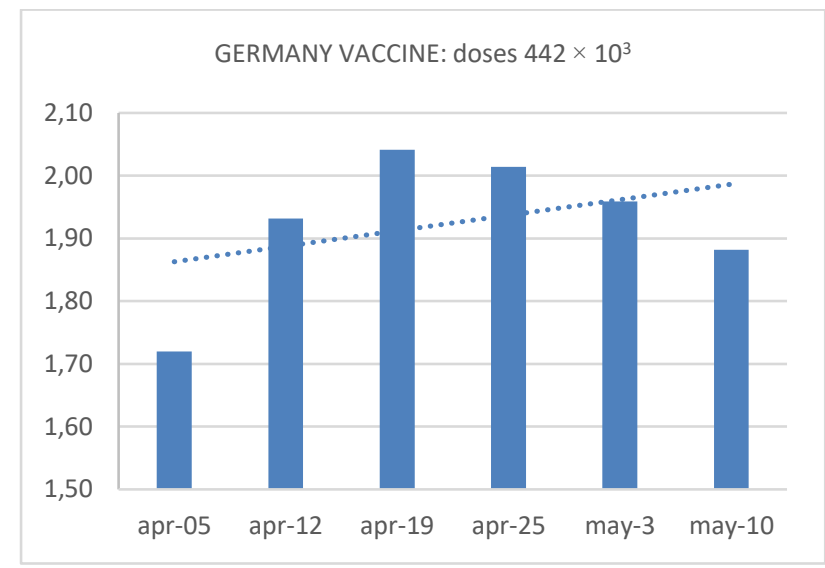

Fig. 5. Trend of the last 6 weeks after the vaccination $(b=44.5)$.

\begin{tabular}{|c|c|c|c|c|c|c|c|}
\hline \multirow{2}{*}{ Country } & \multicolumn{2}{|c|}{ Trends } & \multirow{2}{*}{$\mathrm{P}^{\mathrm{a}}$} & \multirow{2}{*}{ Country } & \multicolumn{2}{|c|}{ Trends } & \multirow{2}{*}{$\mathrm{P}^{\mathrm{a}}$} \\
\hline & $\mathrm{b} W 1$ & b W2 & & & b W1 & b W2 & \\
\hline Armenia & -14.36 & -14.96 & ns & Ireland & -3.22 & -29.06 & $<0.05$ \\
\hline Austria & -20.55 & -20.38 & $\mathrm{~ns}$ & Italy & -7.09 & -11.51 & ns \\
\hline Azerbaijan & -61.75 & -20.22 & ns & Netherlands & -7.33 & -102.24 & $<0.05$ \\
\hline Belgium & -2.20 & -23.45 & $<0.05$ & Norway & -28.93 & -34.53 & $\mathrm{~ns}$ \\
\hline Denmark & -25.00 & -58.75 & ns & Spain & -3.55 & -41.36 & $<0.05$ \\
\hline Estonia & -34.49 & -6.60 & $\mathrm{~ns}$ & Sweden & -10.97 & -24.27 & $<0.05$ \\
\hline Finland & -19.49 & -126.82 & $<0.05$ & Switzerland & -8.196 & -40.10 & $<0.05$ \\
\hline France & -3.85 & -20.27 & $<0.05$ & Turkey & -42.23 & 8.78 & $\mathrm{~ns}$ \\
\hline Germany & -21.37 & 45.40 & ns & United Kingdom & -4.746 & -117.48 & $<0.05$ \\
\hline $\begin{array}{l}\text { b mean val } \\
\text { b mean val } \\
\text { U Mann W } \\
\text { a = Profiler }\end{array}$ & $\begin{array}{l} \pm \mathrm{SD} \\
\pm \mathrm{SD} \\
\text { itney } \mathrm{W} 1\end{array}$ & $\begin{array}{l}=-17.7 \\
=-35.4 \\
\mathrm{~W} 2 \mathrm{p}<\end{array}$ & $\begin{array}{l}16.223 \\
38.985 \\
1 .\end{array}$ & & & & \\
\hline
\end{tabular}

\section{DISCUSSION}

\section{A. Limitations of this Study}

The main limitation of this study is that we have considered the deaths due to COVID-19 during the 6 weeks after the peak of the $\mathrm{W} 1$ and the latest 6 weeks ending on May 10 after the vaccination period. This was only one of the many ways to determine the activity of vaccines and in general was confirming what has been already found in previous studies [15]. According to the expert's opinion, none of the countries was in the conditions of herd 
immunity [17]. Therefore, theoretically we cannot expect the vaccines have a full effect in any of the countries.

Another limitation is the diagnosis of death due to or with COVID-19. The WHO indicates which countries provide suitable and approved data for number of deaths, and these are limited to 49 countries only [18].

However, the pandemic has already lasted for more than one year and the deaths due to COVID-19 were supposed to be assessed in a similar way in all countries by now. As regards deaths due to or with the virus, we can assume that the infection is at least an important concomitant cause.

It was decided to use death rates (mortality) instead of the number of positive swabs (morbidity) owing to the possibility of bias, which was considered lower in the case of death rates. The total number of positive swabs also includes subjects who have been tested more than once and false positive/negative tests. Therefore, the risk of bias was considered much higher. Despite this, the correlation between number of positive swabs and number of deaths was seen to be extremely high [16].

\section{B. The overall Picture}

The virus originated in China in 2019 and, unfortunately, due to globalization it spread around the world.

Many waves of COVID-19 have been recorded in the European countries since its appearance and it has caused a total of about 980,000 deaths. The hope is that vaccinations will generate a suitable barrier against its spread and up to May10-11 about 270 million were administered covering $>14 \%$ of the population with large differences (see Table III). These figures are increasing everyday ad one may expect that the effect also will increase.

One of the concerns was to determine if the decay of deaths could be considered due to the vaccination or if it was also part of the natural decay as it was during the W1.

We have to consider that the present decay is happening in the same season as was for last year, that started in April 2020 and reached the minimum of $10 \times 10^{5}$ on July 10 . After this minimum the deaths started again to grow, due to the virus importation from USA, Brazil, India, and Russia.

However, at this moment in these last countries the death rates are respectively $1.30,6.45,2.02$ and 1.73 and the vaccination coverage is respectively $829,239,135,147 \mathrm{x}$ $10^{3}$ inhabitant. This indicates that, a part of Brazil, they have the same death rates than Europe and similar vaccine coverage, which means that the threat of Europe to reimport the virus should be very limited.

\section{The COVID-19 Variants}

The viral drifts (VOIs or variant of interest) continue to increase [17] and, despite Indian or Brazilian mutation seems to be sensible to the vaccines under use in Europe and USA, it is possible that further VOIs will emerge and create reinfections. For the moment three main VOIs has been identified, 201/501y.V1, 20H501Y.V2, and20J/501Y.V3 that have been isolated respectively in 132,82 , and 52 countries and practically in all the European countries. In terms of coverage for the moment it is not possible to draw any conclusion, however it is possible that any vaccinations can create a barrier against death in case of infection, as it was for the common flu vaccination [16].

Is the time needed to reach herd immunity an unavoidable price to pay or is it an excuse to cover up serious shortcomings in health planning?

The presence of different COVID-19 waves in the period between 2019 and 2021 is typical of many pandemics, and this goes towards answering the important question above.

\section{Not Just Vaccines}

Besides the deaths, the other dramatic aspect of COVID19 is the political situation, which can be summarized in a few words: bad information and bad organization.

The information provided has been extremely uncoordinated and the actions taken have been different and somewhat contradictory in every country. This was understandable during the first COVID-19 wave, when the virus was new. However, even after the decrease in death rate in most of Europe during August 2020, the virus was still found and was very aggressive in big countries such as the USA, Brazil, India, and Russia.

None of the European governments took this aspect seriously and nothing was done to prevent the possible return of outbreaks.

By nature, viruses circulate freely, particularly in these globalized times.

This means that:

a) Disinfection should have been implemented meticulously, particularly in places where people often gather.

b) Border controls should have been carried out in the country of origin and country of arrival to isolate positive cases. These controls would not have been highly detrimental to travel.

c) Hygiene should have been promoted through all media channels, considering that the virus does not only reside in saliva but can be found in all secretions [18], [19].

d) Chronic treatment among the elderly should have been checked by family doctors, and the patients should have been informed that appropriate chronic treatment can ward off death from the virus [23].

Instead, the information that was perceived was that elderly people with chronic diseases were condemned to death [20]-[23].

e) The experts (e.g., virologists, immunologists, and epidemiologists, including those in charge of Scientific Committees) which appeared on TV shows and wrote in the newspapers should have been "peer reviewed" for their specific expertise, as happens for all scientific audiences.

f) no indication was given to the people treated with vaccines about the time needed to generate antibodies. The time needed by our organism to produce antibodies in a sufficient amount, is about 3-4 weeks after the shot

Before this period subjects can be infected and also can spread the virus in case they were infected already.

The organization started to show its faults during the vaccine preparation stage. Countries producing vaccines were not allowed to distribute them in the countries of origin since contracts with the big pharmaceutical companies were required as a precondition to obtaining the shots to cover needs. Production levels were lower than agreed and this led to fighting among countries. Some countries produced vaccines, but the product was not available until the local regulatory authority approved it. In some cases, some 
regions of some countries were able to buy and administer vaccines even without local authority approval.

The picture that emerged was a sort of purgatory where everybody was fighting someone else. But the virus did not care about this fighting and carried on undaunted.

The reason why some countries have not started a vaccination program very late is beyond the scope of this research. Maybe they were not severely infected, because the COVID-19 seems to be more violent in the prosperous countries, but the virus has no borders and the vaccination have cost unaffordable for many of the poor countries.

The obvious consequence is that rich countries will prevail in the competition taking place to obtain vaccines. This means that the virus will be kept viable in poor countries for the next few years.

The severity of the W2 in Europe, before the vaccination program, was much more severe in the poorer countries, mainly located in Eastern Europe [24].

In relation to the costs, it is not difficult to calculate the amount of money needed for the vaccination campaign. Considering a price of between 2 and $19 € /$ shot, the final amount numbers into the billions. Moreover, it is hard to understand why there is such a big difference in the cost of the various vaccines. In any case, it is very big business for the pharmaceutical industry.

\section{CONCLUSIONS}

Vaccination is one of the tools we can use against COVID-19, and one may not say that is not effective, but it does not seem currently to be sufficient to counteract the mortality rates in many countries on its own.

Herd immunity, which it is said is necessary in order to stop deaths due to the virus needs many months before it will be established. Many European countries (38 \%) showed deaths growing despite the vaccination campaign started since about three months.

This can be due to the crowd generated in places were vaccination take place and to the belief that after vaccination everybody will be able to move freely. The time needed by our organism to produce antibodies do not allow this freedom for at least the time necessary to develop them in a sufficient amount, which seems to happen 3-4 weeks after the shot.

Uncontrolled outbreaks can be seen in many countries and indicate that vaccination has to be accompanied by many other measures, such as disinfection of the places where people gather, hygiene (particularly of the oral cavity), and awareness that the virus is found in all secretions/excretions.

The simplest available tools should not be forgotten. The world will probably be threatened by this virus every year and will be particularly severe for the poorest countries until a non-lethal variant becomes predominant as it was for Spanish flu $[25,26]$.

\section{FUNDING}

This research received no financial support.

\section{AUTHOR CONTRIBUTIONS}

UC conceived the trial; GB an SD retrieved all the data, UC carried out the statistical evaluation; UC wrote the text.

\section{CONFLICT OF INTEREST}

There are no conflicts of interest.

\section{ETHICAL STATEMENT}

This manuscript is original, has not been published before, and is not being considered for publication elsewhere. All the authors mentioned in this manuscript have agreed on its authorship, read, and approved it, and given their consent for its submission and subsequent publication.

\section{REFERENCES}

[1] Worldwide Dashboard. Covid 19.who.int/coronavirus/world_ dashboard.

[2] Widge AT, Rouphael NG, Jackson LA et al Durabiility of responses after SARS-Cov-2 mrna-1273 vaccination. NEJM 2020 doi: 10.1056/NEJMc2032195.

[3] Folegatti PM, Ewer KJ, Aley PK et al. Safety and immunogenicity of the ChAdOx1 nCoV -19 vaccine against SARS-CoV-2: a preliminary report of a phase $1 / 2$, single-blind, randomized controlled trial Lancet 2020; 396: 467-478.

[4] Pettersson H, Manley B, Hernandez S, McPillips D. CNN Tracking Covid-19 vaccinations worldwide. CNN 2021 May 22. https://edition.cnn.com/interactive/2021/heath/global-covidvaccinations/.

[5] Jackson LA, Anderson EJ, Rouphael NG, et al. mRNA-1273 Study Group. An mRNA Vaccine against SARS-CoV-2 - Preliminary Report. N Engl J Med. 2020 Nov 12;383(20):1920-1931.

[6] Polack FP, Thomas SJ, Kitchin N, et al. Safety and Efficacy of the BNT162b2 mRNA Covid-19 Vaccine. N Engl J Med 2020; 383: 2603-2615.

[7] Voysey M, Clemens SAC, Madhi SA, et al. Oxford COVID Vaccine Trial Group. Safety and efficacy of the ChAdOx1 nCoV-19 vaccine (AZD1222) against SARS-CoV-2: an interim analysis of four randomized controlled trials in Brazil, South Africa, and the UK Lancet. 2021 Jan 9;397(10269):99-111. doi: 10.1016/S01406736(20)32661-1. Epub 2020 Dec 8. PMID: 33306989.

[8] Logunov DY, Dolzhikova IV, Shcheblyakov DV, et al. Gam-COVIDVac Vaccine Trial Group. Safety and efficacy of an rAd26 and rAd5 vector-based heterologous prime-boost COVID-19 vaccine: an interim analysis of a randomized controlled phase 3 trial in Russia. Lancet 2021 Feb 20;397(10275):671-681.

[9] Sinopharm, China Bio-Beijing Company's new coronavirus inactivated vaccine phase III. December 29, 2020.

[10] https://www.nytimes.com/2021/01/07/business/china-coronavirusvaccine-sinovac.html.

[11] Johnson \& Johnson Announces Single-Shot Janssen COVID-19 Vaccine Candidate Met Primary E2ndpoints in Interim Analysis of its Phase 3 ENSEMBLE Trial. J\&J Press Release. January 29, 2021.

[12] http://www.cansinotech.com/html/1///179/180/654.html.

[13] https://www.bharatbiotech.com/images/press/covaxin-phase3efficacy-results.pdf.

[14] https://www.cnews.fr/monde/2021-02-21/spoutnik-v-epivaccoronakovivak-que-sait-des-trois-vaccins-russes-1049954.

[15] Cornelli U, Belcaro G, Recchia M. COVID-19 vaccination in Europe facts, hopes and fakes. 2021 Scolar Press Chisinau-Moldovia.

[16] Cornelli U, Belcaro G, Cesarone MR, Recchia M, Cotellese R. The COVID-19 History in Italy: Correlations with Environmental, Demographic Variables and Chronic Diseases Therapy. JMCRR 2020; 4: 1-13.

[17] COVID-19 Weekly Epidemiological Update WHO report April 11 2021.

[18] Mayers C, Robinson R, Milici J et al. Lowering the transmission and spread of human coronavirus JMV 2020; 1-8 DOI: 10.1002/jmv.26514. 
[19] Belcaro G, Cornelli U, Cesarone MR, Feregalli B, Bombardelli e et al. Seven immediate, low..cost management strategies for Covid Exploiting viral thermolability: possible immediate solutions. BJSTR 2020 doi: 10.26717/BJSTR.2020.27.004506.

[20] Cornelli U, Belcaro G, Cesarone MR, Recchia M, Cotellese R. Covid19 Aging and Chronic diseases. Micribiol Infect Dis 2020; 4(6):1-6.

[21] Petrilli CM, Jones SA, Yang J et al. Factors associated with hospital admission and critical illnesses among 5279 people with coronavirus disease 2019 in New York City: prospective cohort study. BMJ 2020:369:m1966.

[22] Williamson EJ, Walker AJ, Bhaskaran K et al. Factors associated with COVID-19-relates death using OpenSAFELY. Nature 2020; 854: 430-436.
[23] O'Heam M, Liu J, Cudhea F et al. Coronavirus disease 2019 hospitalizations attributable to cardiometabolic conditions in the United States: a comparative risk assessment analysis. JAHA 2021:10:e0119259. DOI: 10.1161/Jaha.120.019259.

[24] Cornelli U, Belcaro G, Recchia M. The many waves of COVID-19 in European countries. LAP Lambert Academic Publishing -Mauritius 2021:20.

[25] Taunenberger JK, !918 influenza: the mother of all pandemics. Emerging Inf Dis 2006; 12(1):15-22.

[26] Akin L, Gözel MG. Understanding dynamics of pandemics. Turkish J Med Sci. 2020; 50: 525-519. 